Aksiologiya: Jurnal Pengabdian Kepada Masyarakat

Vol.4, No.2, Agustus 2020 Hal 153 - 160

ISSN 2528-4967 (print) dan ISSN 2548-219X (online)

\title{
Deteksi Dini Faktor Risiko Penyakit Tidak Menular Pada Masyarakat Desa Andepali Kecamatan Sampara Kabupaten Konawe
}

\author{
I Putu Sudayasa' ${ }^{1}$ Muhammad Fathur Rahman', Amiruddin Eso ${ }^{3}$, \\ Jamaluddin $^{4}$, Parawansah ${ }^{5}$ La Ode Alifariki ${ }^{6}$, Arimaswati ${ }^{7}$, Andi Noor \\ Kholidha $^{8}$ \\ ${ }^{1-8}$ Program Studi Kedokteran Fakultas Kedokteran Universitas Halu Oleo Kendari \\ Email: dr.putusudayasa@uho.ac.id ${ }^{1}$, Muh.Fathur_Rahman@gmail.com2, \\ Amiruddin@gmail.com ${ }^{3}$ Jamaluddin@gmail.com ${ }^{4}$, Parawansah@gmail.com ${ }^{5}$, \\ ners_riki@yahoo.co.id ${ }^{6}$,Arimaswati@gmail.com ${ }^{7}$, Kholidha@gmail.com
}

\begin{abstract}
ABSTRAK
Penyakit Tidak Menular (PTM) merupakan penyakit yang tidak ditularkan dan tidak ditransmisikan kepada orang lain dengan bentuk kontak apapun, menyebabkan kematian dan membunuh sekitar 35 juta manusia setiap tahunnya, atau $60 \%$ dari seluruh kematian secara global, dengan $80 \%$ pervalensi pada negara berkembang. PTM, khususnya penyakit kardiovaskuler, kanker, penyakit pernapasan kronis, dan diabetes merupakan ancaman utama bagi kesehatan dan perkembangan manusia saat ini. Tujuan pengabdian masyarakat yang terintegrasi Kuliah Kerja Nyata (KKN) Tematik, untuk mendeteksi faktor risiko penyakit tidak menular, pada masyarakat Kecamatan Sampara, Kabupaten Konawe. Jenis kegiatan yang dilakukan berupa penyuluhan kesehatan, pemeriksaan tekanan darah, kadar kolesterol, gula darah sewaktu dan asam urat. Telah dilakukan skrining dan deteksi dini faktor risiko penyakit tidak menular terhadap 67 orang responden, meliputi 14 laki-laki dan 53 perempuan. Pada hasil pemeriksaan tekanan darah, didapatkan jumlah yang mengalami hipertensi $28,35 \%$, normotensi $67,16 \%$, dan hipotensi $4,47 \%$. Pada pemeriksaan Kolesterol Total, didapatkan kolesterol dalam batas normal 2,38\% dan tinggi 37,31\%. Hasil pemeriksaan Gula Darah Sewaktu (GDS), didapatkan kadar GDS dalam batas normal 85,07\% dan kadar GDS tinggi 14,92\%. Pada pemeriksaan Asam Urat didapatkan dalam batas normal adalah 91,04\% dan tinggi 8,95\%. Perlu memaksimalkan kegiatan posbindu dalam mereduksi kejadian penyakit tidak menular melalui penyuluhan dan screening.
\end{abstract}

Kata kunci : Faktor Risiko; Penyakit Tidak Menular

\section{Early Detection of Non-communicable Disease Risk Factors in Andepali Village Community, Sampara District, Konawe Regency}

ABSTRACT

Non-communicable disease (PTM) is a disease that is not transmitted and is not transmitted to others by any form of contact, causing death and killing around 35 million people each year, or $60 \%$ of all deaths globally, with $80 \%$ prevalence in developing countries. PTM, especially cardiovascular disease, cancer, chronic respiratory diseases, and diabetes are the main threats to human health and development today. The purpose of integrated community service is the Thematic Real Work Study (KKN), to detect risk factors for non-communicable diseases, in the community of Sampara District, Konawe Regency. The method of activity in the form of health education, blood pressure, cholesterol levels, blood sugar and uric acid. Screening and early detection of risk factors for non- 
communicable diseases have been carried out on 67 respondents, including 14 men and 53 women. On the results of blood pressure examination, it was found that the amount of hypertension was $28.35 \%$, normotension $67.16 \%$ and hypotension $4.47 \%$. In the examination of Total Cholesterol, cholesterol was found to be within the normal limit of $2.38 \%$ and $37.31 \%$ high. Examination results of Blood Sugar (GDS), obtained levels of GDS in the normal range of $85.07 \%$ and high GDS levels of $14.92 \%$. In the examination of Gout found in the normal range is $91.04 \%$ and high $8.95 \%$.

Keywords: gout; blood sugar; cholesterol; non-communicable diseases; blood pressure

\section{PENDAHULUAN}

Salah satu masalah yang dihadapi dalam pembangunan kesehatan saat ini adalah terjadinya pergeseran pola penyakit dari penyakit menular ke penyakit tidak menular. Tingginya prevalensi penyakit tidak menular membawa dampak terhadap menurunnya produksitivitas dan gangguan pada pemenuhan aktivitas sehari-hari. Laporan dari WHO menunjukkan bahwa PTM sejauh ini merupakan penyebab utama kematian di dunia, yang mewakili $63 \%$ dari semua kematian tahunan. PTM membunuh lebih dari 36 juta orang setiap tahun. Kematian akibat penyakit kardiovaskular paling banyak disebabkan oleh PTM yaitu sebanyak 17,3 juta orang per tahun, diikuti oleh kanker (7,6 juta), penyakit pernafasan (4,2 juta), dan DM (1,3 juta). Keempat kelompok jenis penyakit ini menyebabkan sekitar $80 \%$ dari semua kematian PTM. Penyakit tidak menular diketahui sebagai penyakit yang tidak dapat disebarkan dari seseorang terhadap orang lain. Terdapat empat tipe utama penyakit tidak menular yaitu penyakit kardiovaskuler, kanker, penyakit pernapasan kronis, dan diabetes. Pola hidup modern telah mengubah sikap dan perilaku manusia, termasuk pola makan, merokok, konsumsi alkohol serta obat-obatan sebagai gaya hidup sehingga penderita penyakit degeneratif (penyakit karena penurunan fungsi organ tubuh) semakin meningkat dan mengancam kehidupan. (Kemenkes, 2019)

Akibat perilaku manusia, lingkungan hidup dieksploitasi sedemikian rupa sampai menjadi tidak ramah terhadap kehidupan manusia, sehingga meningkatkan jumlah penderita penyakit paru kronis yang seringkali berakhir dengan kematian. Berbagai penyakit kanker juga dapat dipicu oleh bermacam bahan kimia yang bersifat karsinogenik, kondisi lingkungan, serta perilaku manusia (Darmawan, 2016)

Penyakit tidak menular telah menjadi kelompok penyakit yang sulit untuk didefinisikan. Istilah penyakit tidak menular menjadi sebuah ironi karena beberapa penyakit yang termasuk seperti kanker leher rahim, perut, dan hati sebagian disebabkan oleh infeksi organisme. Namun, empat perilakusepertipenggunaantembakau, konsumsi alkohol, pola makan yang buruk, dan kurangnya aktivitas fisik merupakan perilaku yang menjadi faktor risiko dan berhubungan erat dengan empat penyakit tidak menular utama (penyakit kardiovaskuler, kanker, penyakit pernapasan kronis, dan diabetes) yang mencapai $80 \%$ 
menyebabkan kematian dari kelompok penyakit tidak menular (Kemenkes, 2017).

Penyakit tidak menular muncul dari kombinasi faktor risiko yang tidak dapat dimodifikasi dan faktor risiko yang dapat dimodifikasi. Fakor risiko yang tidak dapat dimodifikasi oleh individu adalah usia, jenis kelamin, dan genetika. Sedangkan faktor risiko yang dapat dimodifikasi adalah faktor yang dapat diubah melalui kesadaran individuitusendiridanintervensisosial (Alifariki, 2015). Tingginya kejadian dan kematian akibat PTM menjadikan pengendaliannya penting dilakukan. Deteksi dini serta pengobatan yang tepat membuat pengendalian PTM lebih baik. Surveilans kasus dan faktor risiko PTM menjadi strategi untuk pencegahan, pengendalian tepat serta terpadu oleh pemerintah, swasta, dan masyarakat (Umuyana et al, 2015). Penyuluhan, pemeriksaan serta Surveilans faktor risiko PTM merupakan bentuk upaya kesehatan dalam mencegah peningkatan prevalensi penyakit tidak menular (Indriyawati, dkk., 2018)

Kegiatan program pengabdian dosen FK UHO yang terintegrasi KKN Tematik berupa penyuluhan kepada masyarakat tentang faktor risiko dari penyakit tidak menular (PTM), dilanjutkan dengan pemeriksaan faktor risiko dari penyakit tidak menular dari masyarakat di wilayah Kecamatan Sampara Konawe. Alasan pemilihan lokasi kegiatan adalah bahwa berdasarkan laporan tahunan Puskesmas Sampara menunjukkan bahwa prevalensi penyakit tidak menular seperti hipertensi, DM, asam urat selalu masuk dalam 10 jenis penyakit terbanyak setiap tahunnya.

Informasi kesehatan dari pemeriksaan faktor risiko PTM dalam menggambarkan pola penyakit secara akurat sangat penting untuk menjadi dasar penentuan prioritas dalam pengambilan keputusan pencegahan serta pengendalian PTM.

\section{METODE PELAKSANAAN KEGIATAN}

Metode yang digunakan dalam kegiatan ini meliputi penyuluhan yang dilanjutkan dengan demonstrasi pemeriksaan kesehatan, dan diskusi grup tentang konseling, informasi, dan edukasi. Tahapan dalam kegiatan yaitu sebagai berikut:

1. Perencanaan dan persiapan

Tim pelaksana berkoordinasi dengan pihak mitra dalam hal ini Kepala Desa mengenai peserta, waktu, tempat dan susunan acara kegiatan. Selanjutnya tim pelaksana mempersiapkan alat dan bahan yang digunakan dalam kegiatan. Persiapan ini difokuskan dengan menyiapkan semua media dan perlengkapan yang dibutuhkan untuk melaksanakan kegiatan ini.

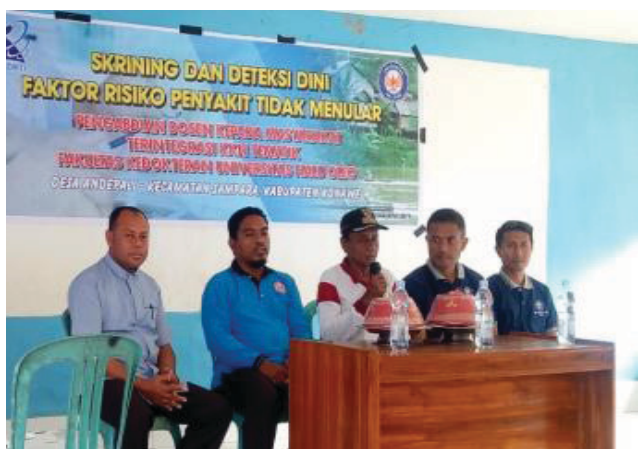

Gambar 1. Penyuluhan Faktor Risiko PTM 
2. Sosialisasi kegiatan

Sosialisasi dilaksanakan untuk memberikan pengumuman kepada masyarakat Desa tentang pemeriksaan yang akan dilaksanakan.

3. Pemeriksaan kesehatan

Kegiatan dilakukan dengan cara memeriksa tekanan darah, kadar gula darah, asam urat, dan kolesterol dilanjutkan dengan konsultasi hasil secara bergilir. Pemeriksaan dilaksanakan dengan menggunakan alat test digital. Masyarakat yang datang dicatat identitasnya (nama, umur, jenis kelamin) lalu dipersilahkan menuju meja pemeriksaan. Masyarakat memeriksa tekanan darah, kadar gula darah, asam urat, kolesterol lalu diberikan kertas hasil pemeriksaan untuk konsultasi bersama pakar secara dua arah.

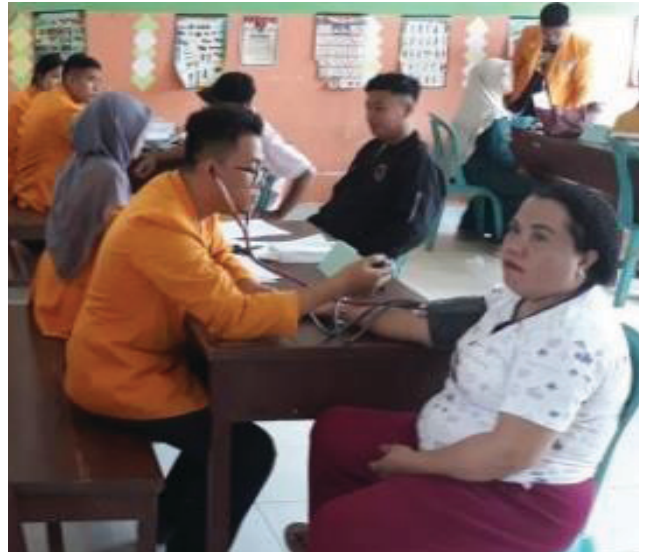

Gambar 2. Pengukuran Tekanan Darah

4. Tindak lanjut

Tindak lanjut yang dilakukan atas hasil pemeriksaan kesehatan khususnya bagi masyarakat yang memiliki masalah kesehatan adalah melakukan kunjungan rumah yang dilakukan oleh mahasiswa.

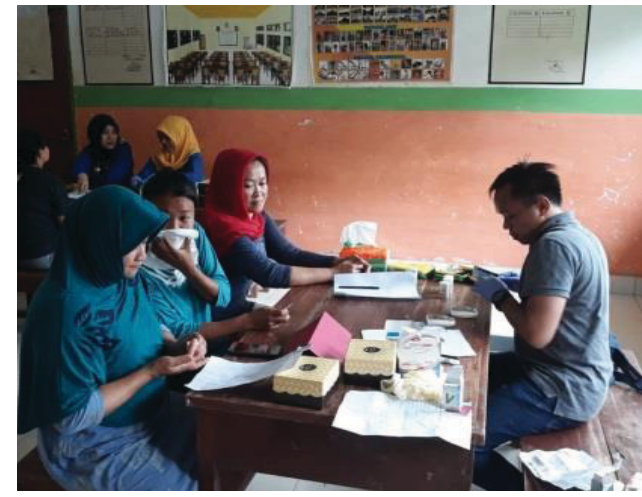

Gambar 3. Pemeriksaan kadar gula darah, dan kadar asam urat

\section{PELAKSANAAN DAN HASIL KEGIATAN}

Kegiatan dilaksanakan pada bulan Agustus 2019, di Desa Andepali, Kecamatan Sampara, dengan jumlah 67 orang. Metode yang digunakan pada kegiatan pengabdian kepada masyarakat yaitu : Penyuluhan PTM bertujuan untuk menjelaskan kepada masyarakat tentang bahaya PTM serta cara mendeteksi secara dini untuk mencegah PTM di Balai Desa Andepali. Penyuluhan PTM ini dilaksanakan hanya satu kali. Saat penyuluhan PTM, tampak masyarakat antusias mengikuti penyuluhan dan banyak masyarakat yang bertanya dan berdiskusi dengan pemateri. Pemeriksaan faktor risiko PTM, dilakukan di Balai desa Andepali, setelah dilakukan penyuluhan faktor risiko PTM.

Rekapitulasi hasil pemeriksaan responden yang telah dilakukan pemeriksaan sebanyak 67 orang, sebagaimana tercantum dalam tabel 1. 
Tabel 1. Distribusi Hasil Pemeriksaan

\begin{tabular}{|c|c|c|c|c|c|c|c|}
\hline \multirow[t]{2}{*}{ No. } & \multirow[t]{2}{*}{ Hasil Pemeriksaan } & \multicolumn{2}{|c|}{ Laki-laki } & \multicolumn{2}{|c|}{ Perempuan } & \multicolumn{2}{|c|}{ Jumlah } \\
\hline & & $\mathrm{n}$ & $\%$ & $\mathrm{n}$ & $\%$ & $\mathrm{n}$ & $\%$ \\
\hline \multirow[t]{4}{*}{1.} & Tekanan darah & & & & & & \\
\hline & a. Hipertensi & 2 & 2,98 & 17 & 25,37 & 19 & 28,35 \\
\hline & b. Normotensi & 12 & 17,91 & 33 & 49,25 & 45 & 67,16 \\
\hline & c. Hipotensi & 0 & 0 & 3 & 4,47 & 3 & 4,47 \\
\hline \multirow[t]{3}{*}{2.} & Kolesterol total & & & & & & \\
\hline & a. Normal & 8 & 11,94 & 34 & 50,74 & 42 & 62,68 \\
\hline & b. Tinggi & 6 & 8,95 & 19 & 28,35 & 25 & 37,31 \\
\hline \multirow[t]{3}{*}{3.} & Gula darah sewaktu & & & & & & \\
\hline & a. Normal & 12 & 17,91 & 45 & 67,16 & 57 & 85,07 \\
\hline & b. Tinggi & 2 & 2,98 & 8 & 11,94 & 10 & 14,92 \\
\hline \multirow[t]{4}{*}{4.} & Asam urat & & & & & & \\
\hline & a. Normal & 14 & 20,89 & 47 & 70,14 & 61 & 91,04 \\
\hline & b. Tinggi & 0 & 0 & 6 & 8,95 & 6 & 8,95 \\
\hline & Total & 14 & & 53 & & 67 & 100 \\
\hline
\end{tabular}

Sumber : Data Primer, 2019

Menurut data pada tabel 1, diketahui bahwa jumlah sampel yang mengikuti pemeriksaan tekanan darah, gula darah sewaktu dan asam urat sebanyak 67 orang terbagi dalam 14 laki-laki dan 53 perempuan. Pada hasil pemeriksaan tekanan darah, didapatkan laki-laki sebanyak 2,98\% mengalami hipertensi, sedangkan $17,91 \%$ normotensi dan tidak ada yang mengalami hipotensi.

Hal ini berbeda dengan hasil pemeriksaan tekanan darah pada perempuan dimana didapatkan $25,27 \%$ mengalami hipertensi, hanya $49,25 \%$ normotensi dan $4,47 \%$ hipotensi, sehingga jumlah rata- rata yang mengalami hipertensi $28,35 \%$, normotensi $67,16 \%$, dan hipotensi $4,47 \%$. Selanjutnya pada pemeriksaan Kolesterol Total, didapatkan sampel laki-laki 11,94\% normal dan 2,98\% tinggi dan pada perempuan didapatkan $50,74 \%$ normal dan 28,35\% tinggi, sehingga rata-rata kolesterol dalam batas normal adalah $62,38 \%$ dan tinggi $37,31 \%$.

Selanjutnya pada hasil pemeriksaan gula darah sewaktu (GDS), sampel laki-laki didapatkan $17,91 \%$ normal dan $2,98 \%$ tinggi dan pada perempuan didapatkan $67,16 \%$ normal dan 11,94\% tinggi, sehingga rata-rata kadar GDS dalam batas normal adalah $85,07 \%$ dan kadar GDS tinggi $14,92 \%$. Selanjutnya pada pemeriksaan Asam Urat sampel lakilaki didapatkan 20,89\% normal dan pada perempuan didapatkan $70,14 \%$ normal dan 8,95\% tinggi sehingga rata-rata Asam Urat dalam batas normal adalah 91,04\% dan tinggi $8,95 \%$.

Hasil pengabdian masyarakat ini, merupakan kelanjutan dari kegiatan skrining faktor risiko gizi tahun 2018 pada masyarakat Desa Andepali, Kecamatan Sampara, Konawe, yang didapatkan jumlah responden status gizi berlebih $16,7 \%$, obesitas $30,6 \%$, 
sedangkan data lingkar pinggang tidak normal 52,8\% (Sudayasa et al, 2019). Berdasarkan profil WHO, mengenai penyakit tidak menular di Asia Tenggara, ada lima penyakit tidak menular dengan angka kesakitan dan kematian yang tinggi, yaitu penyakit kardiovaskuler, kanker, penyakit pernapasan kronis, diabetes mellitus, dan cedera. Empat terbanyak dari penyakit tidak menular yaitu penyakit kardiovaskuler, kanker, penyakit pernapasan kronis, dan diabetes mellitus (Pranandari, dkk. 2017)

Hipertensi merupakan salah satu penyakit tidak menular yang menjadi masalah kesehatan penting di seluruh dunia karena prevalensinya yang tinggi dan terus meningkat serta hubungannya dengan penyakit kardiovaskuler, stroke, retinopati diabetika, dan penyakit ginjal. Hipertensi juga menjadi faktor risiko ketiga terbesar penyebab kematian dini. The Third National Health and Nutrition Examination Survey mengungkapkan bahwa hipertensi mampu meningkatkan risiko penyakit jantung koroner sebesar $12 \%$ dan meningkatkan risiko stroke sebesar 24\%. Upayarutin pemeriksaan tekanan darah dan memahami faktor risiko yang menjadi pencetus gangguan kardiovaskuler, perlu dilakukan juga dari lingkungan dunia pendidikan khususnya kampus kesehatan dan kedokteran (Utama, et al, 2018).

Penyebab dari penyakit hipertensi adalah faktor risiko yang multikausal (bermacam-macam), bahkan tidak jelas. Faktor risiko hipertensi yang tidak dapat diubah seperti umur, ras/ suku, jenis kelamin, genetik dan faktor risiko hipertensi yang dapat diubah seperti obesitas, stres, kebiasaan makan tinggi kolesterol dan natrium, merokok, tipe kepribadian, dan diabetes mellitus. Pencegahan yang dapat dilakukan melalui kegiatan posbindu, yaitu dengan memodifikasi gaya hidup dimana ada beberapa faktor risiko yang dapat diubah untuk mengurangi angka kejadian PTM, misalnya: berolah raga secara teratur, mengonsumsi buah dan sayur, kurangi makan makanan berlemak, tidak merokok dan konsumsi alkohol (Rahmayanti, et al, 2017).

Perlunya kegiatan yang menggerakkan dan memotivasi masyarakat untuk hidup sehat dan mengubah gaya hidup, yaitu dengan Gerakan Masyarakat Sehat atau Germas, melalui pelayanan pos pembinaan terpadi (posbindu) (Umayana, et al, 2015). Program Germas harus terus digalakkan untuk meningkatkan kesadaran masyarakat menjalankan pola hidup sehat. Upaya pencegahan jauh lebih baik dibandingkan pengobatan ketika sudah terjangkit Penyakit. Semakin meningkatnya kejadian PTM, maka perlu adanya edukasi dan pendampingan kepada masyarakat untuk melaksanakan deteksi dini atau skrining terhadap PTM, terutama pada kelompok berisiko. Masyarakat harus selalu diajak untuk mengenali penyakitnya. Penting untuk melaksanakan pengabdian kepada masyarakat tentang skrining dan pendampingan pencegahan Penyakit Tidak Menular di masyarakat. 
(Warganegara, et al, 2016).

Setelah pelaksanaan kegiatan penyuluhan PTM dan skrining faktor risiko penyakitPTM, maka selanjutnya sebagai bentuk tindak lanjut kegiatan, mahasiswa melakukan kunjungan rumah untuk menindaklanjuti aktivitas yang dilakukan oleh masyarakat dalam mencegah kejadian penyakit tidak menular (PTM).

\section{SIMPULAN}

Telah dilakukan skrining dan deteksi dini fator risiko penyakit tidak menular terhadap 67 orang responden, didapatkan lebih banyak normotensi 67,16\%. Pada pemeriksaan Kolesterol Total, didapatkan kolesterol dalam batastinggi37,31\%.Hasilpemeriksaan gula darah sewaktu(GDS), didapatkan rata-rata kadar GDS dalam batas normal 85,07 \%. Pada pemeriksaan Asam Urat didapatkan dalam batas normal adalah 91,04\%.

\section{UCAPAN TERIMA KASIH}

Terima kasih kepada tim pengabdian dosen, mahasiswa KKN, pimpinan FK UHO, Camat Sampara dan Kepala Desa Andepali, Ketua LPPM UHO atas kepercayaan yang telah diberikan kepada tim pengamas melalui kegiatan pengabdian kepada masyarakat dosen terintegrasi KKN Tematik Universitas Halu Oleo dengan nomor kontrak 1386b/Un29.20/ $\mathrm{PPM} / 2019$

\section{DAFTAR PUSTAKA}

Alifariki LO. Analisis Faktor Determinan Proksi Kejadian Hipertensi di Poliklinik Interna BLUD RSU Provinsi
Sulawesi Tenggara. Medula. 2015;3(1):214-23.

Darmawan, A. 2016. Epidemiologi Penyakit Menular dan Penyakit Tidak Menular. JMJ, Volume 4, Nomor 2, Fakultas Kedokteron dan Ilmu Kesehatan. Universitas Jambi, hal 195-202

Indriyawati, N.,Widodo, Nurul M., Priyatno, D., Jannah, M., 2018. Skrining dan Pemdampingan Penyakit Tidak Menular di Masyarakat, e-journal Jurusan Keperawatan, Poltekkes Kemenkes. Semarang, LINK Vol. 14, No. 1, hal. 50-54

Kemenkes, RI., 2019, Buku Pedoman Pencegahan Penyakit Tidak Menular, Direktorat Pencegahan dan Pengendalian Penyakit Tidak Menular, Kemenkes RI, Jakarta.

Kemenkes, RI., 2017, Rencana Aksi Pengendalian Penyakit Tidak Menular Tahun 20152019, Direktorat Pencegahan dan Pengendalian Penyakit Tidak Menular, Kemenkes RI, Jakarta.

Pranandari, L. Lutfy., Septo, Pawales Arso, Eka, Yunila Fatmasari. 2017, Analisis Implementasi Program Pos Pembinaan Terpadu Penyakit Tidak Menular (POSBINDU PTM) di Kecamatan Banguntapan, Kabupaten Bantul, Jurnal Kesehatan Masyarakat, Universitas Diponegoro, Volume 5 Nomor 4

Rahmayanti, Elyda, Hargono, Arif, 2017, Implementasi Surveilans Faktor Risiko Penyakit Tidak Menular Berbasis POSBINDU Berdasarkan Atribut Surveilans, Jurnal Berkala Epidemiologi, Vol. 5, No. 3, Fakultas Kesehatan Masyarakat Unair, Jawa Timur, hal.276-285

Sudayasa, I Putu, Hartati, Bahtiar, 2019, Family Nutrition 
Improvement Effort Though Nutrition Management of Pokea Clam Based on Enviromental Health, Jurnal Pengabdian Kepada Masyarakat (Indonesian Journal of Community Engagement) Vol.5, Nomor 2, Agustus 2019, hal.222-236, ISSN:2541-5883

Umayana, Haniek Try, Cahyati, Widya Hary, 2015, Dukungan Keluarga dan Tokoh Masyarakat Terhadap Keaktifan Penduduk ke Posbindu Penyakit Tidak Menular, Jurnal Kesehatan Masyarakat, Universitas Negeri Semarang, KEMAS, 11 (1) (2015) 96-101.

Utama, Feranita, Rahmiati, Anita, Alamsari. Halidazia, Lihwana, Mia Asni, 2018, Gambaran Penyakit Tidak Menular di Universitas Sriwijaya, Jurnal Kesehatan Vol. 11. No. 2. Fakultas Kesehatan Masyarakat, Uiniversitas Sriwijaya

Warganegara, Efrida, Nur, Nida Nabilah.2016, Faktor Risiko Perilaku Penyakit Tidak Menular, jurnal Majority, Volume 5, Nomor 3, hal. 88-94 